Org. Lett. Ms OLO61246x

Title: Perylene-3,4,9,10-tetracarboxylic acid bisimide dye as an Artificial DNA base surrogate

Authors: Clemens Wagner, Hans-Achim Wagenknecht*

\title{
Compound 4:
}

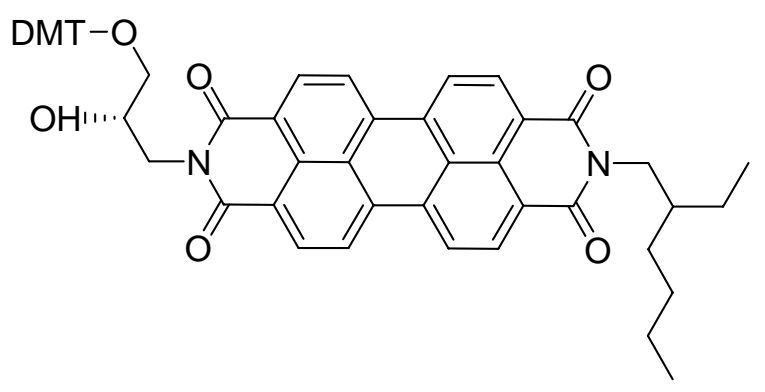

\section{H NMR}

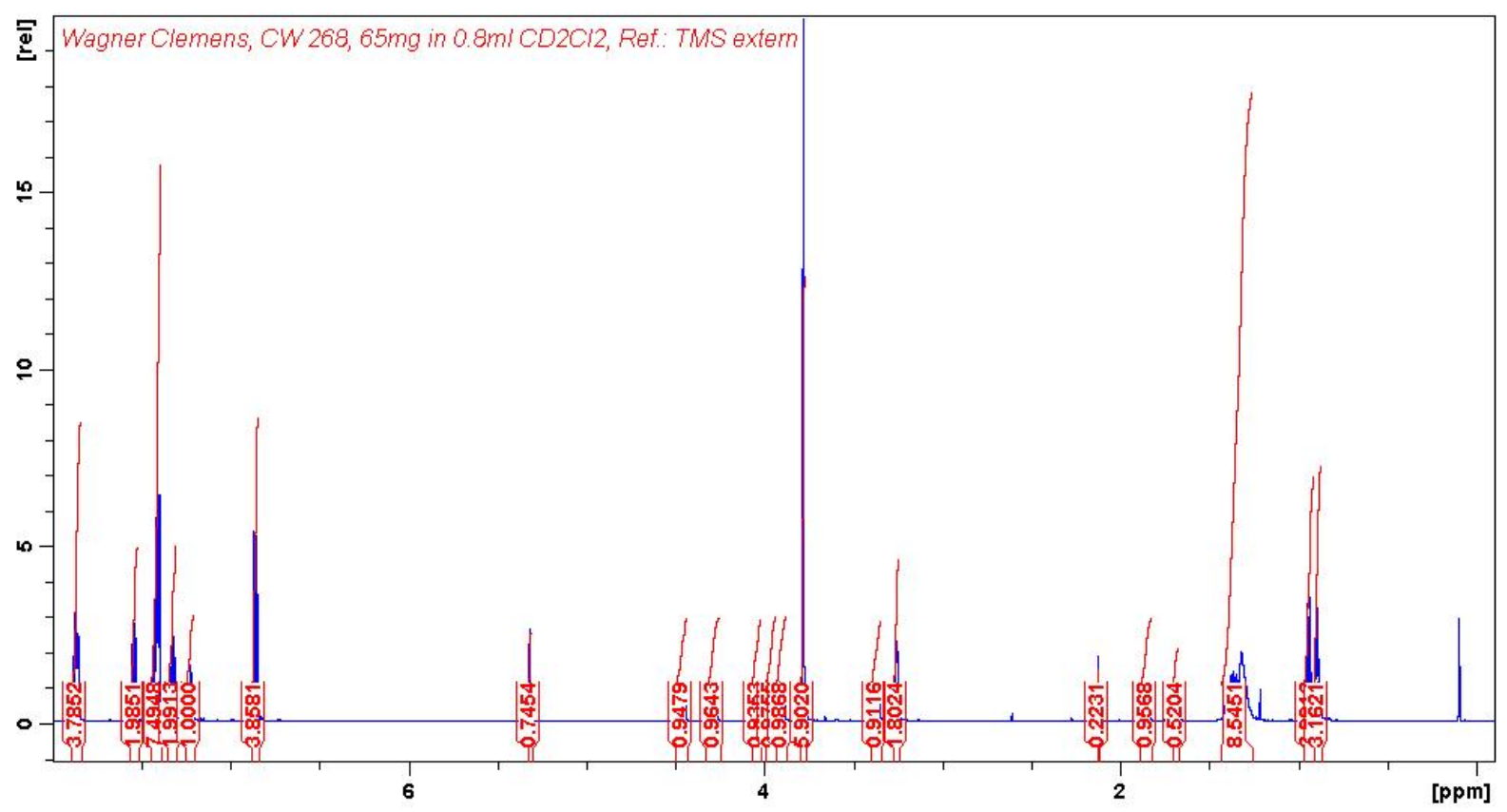



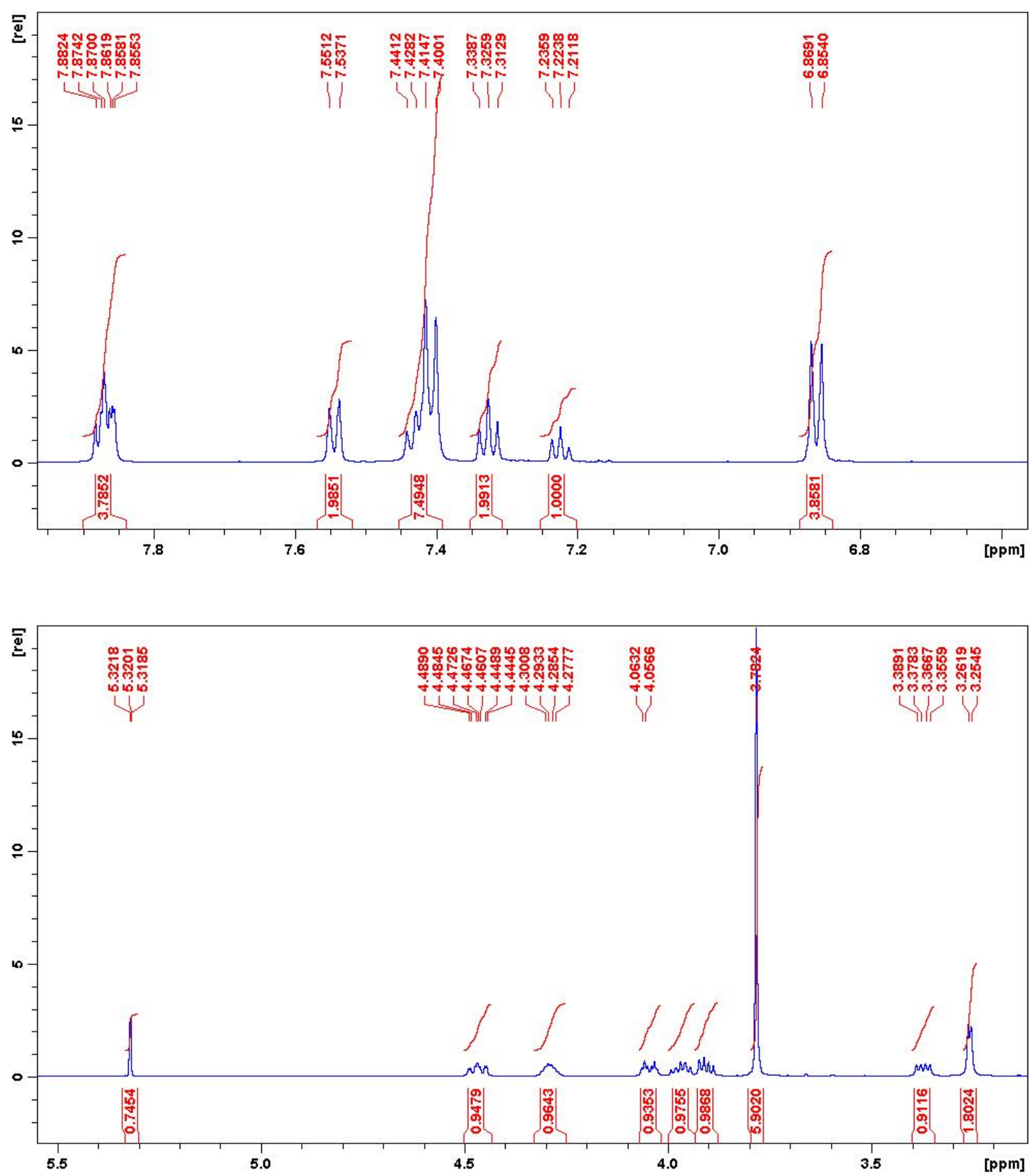


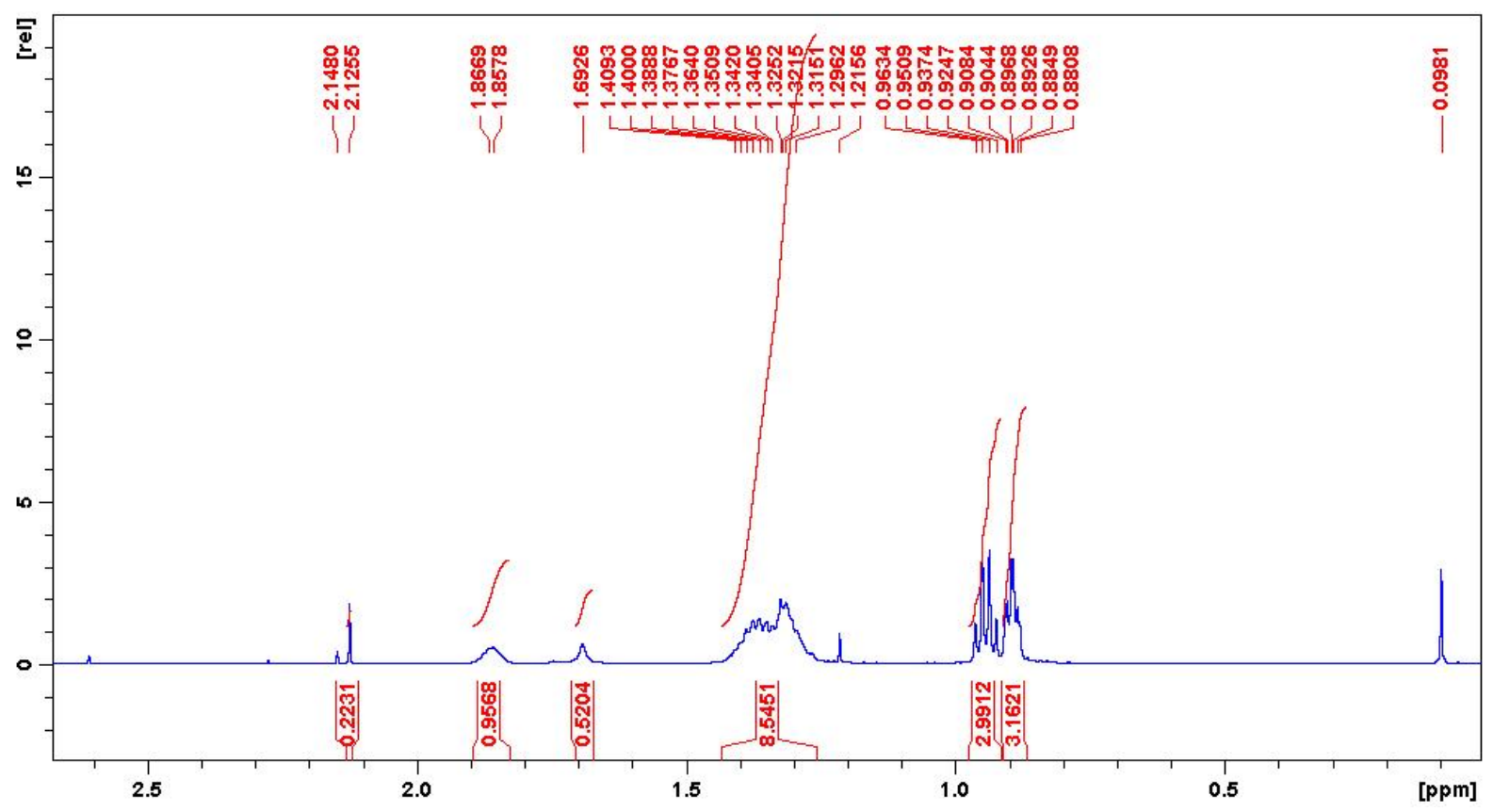

13C NMR

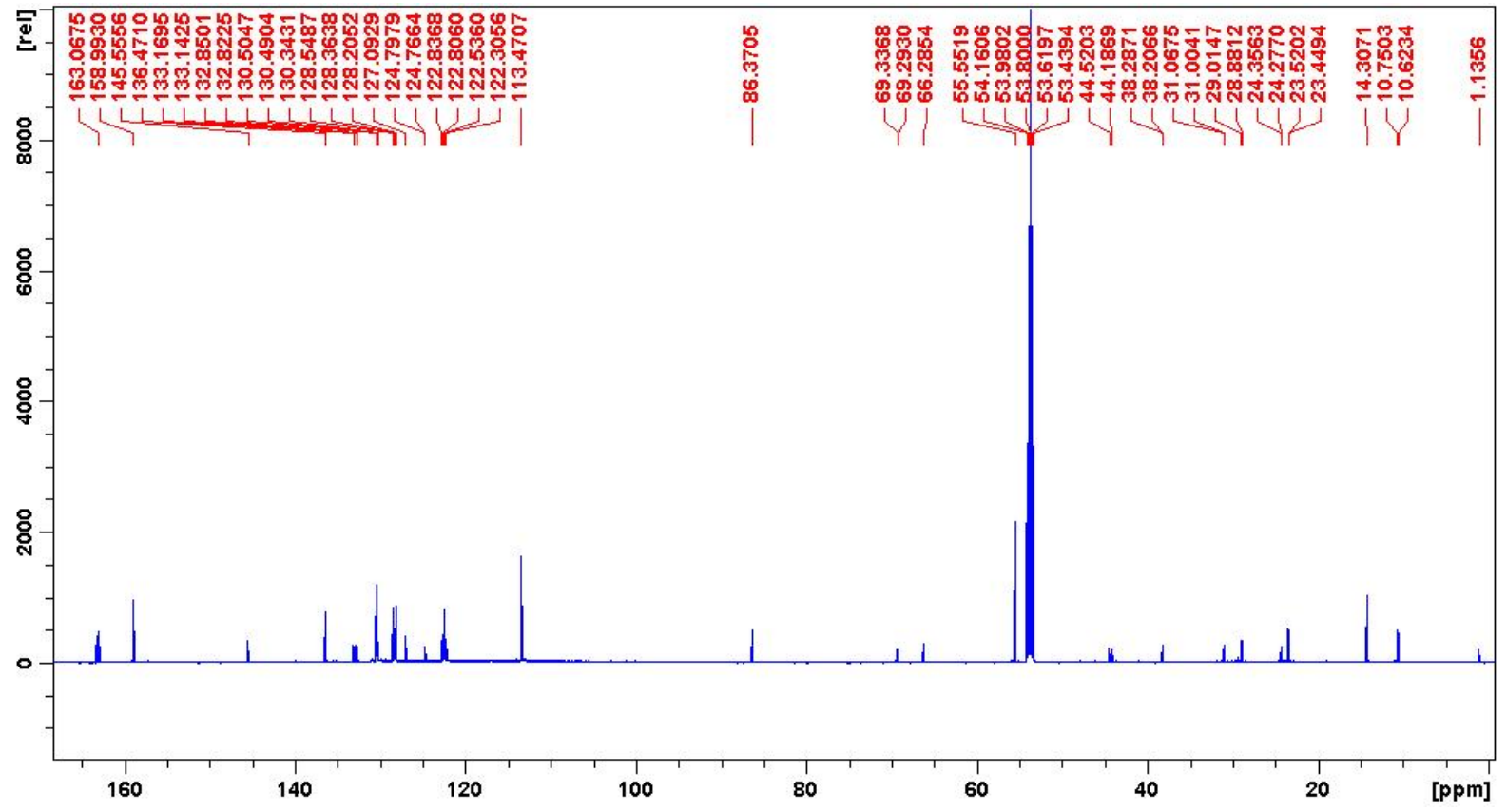



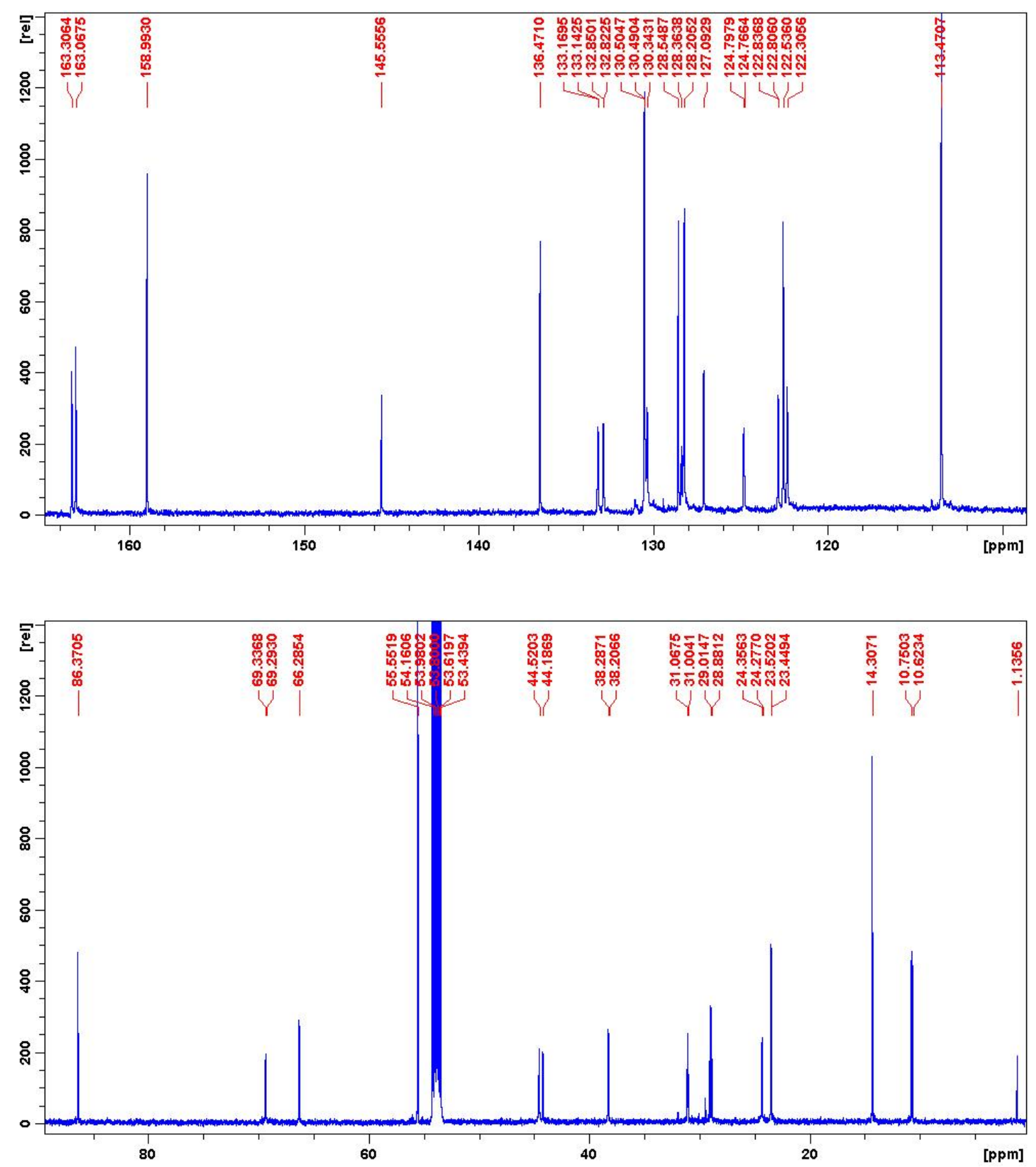
ESI-MS

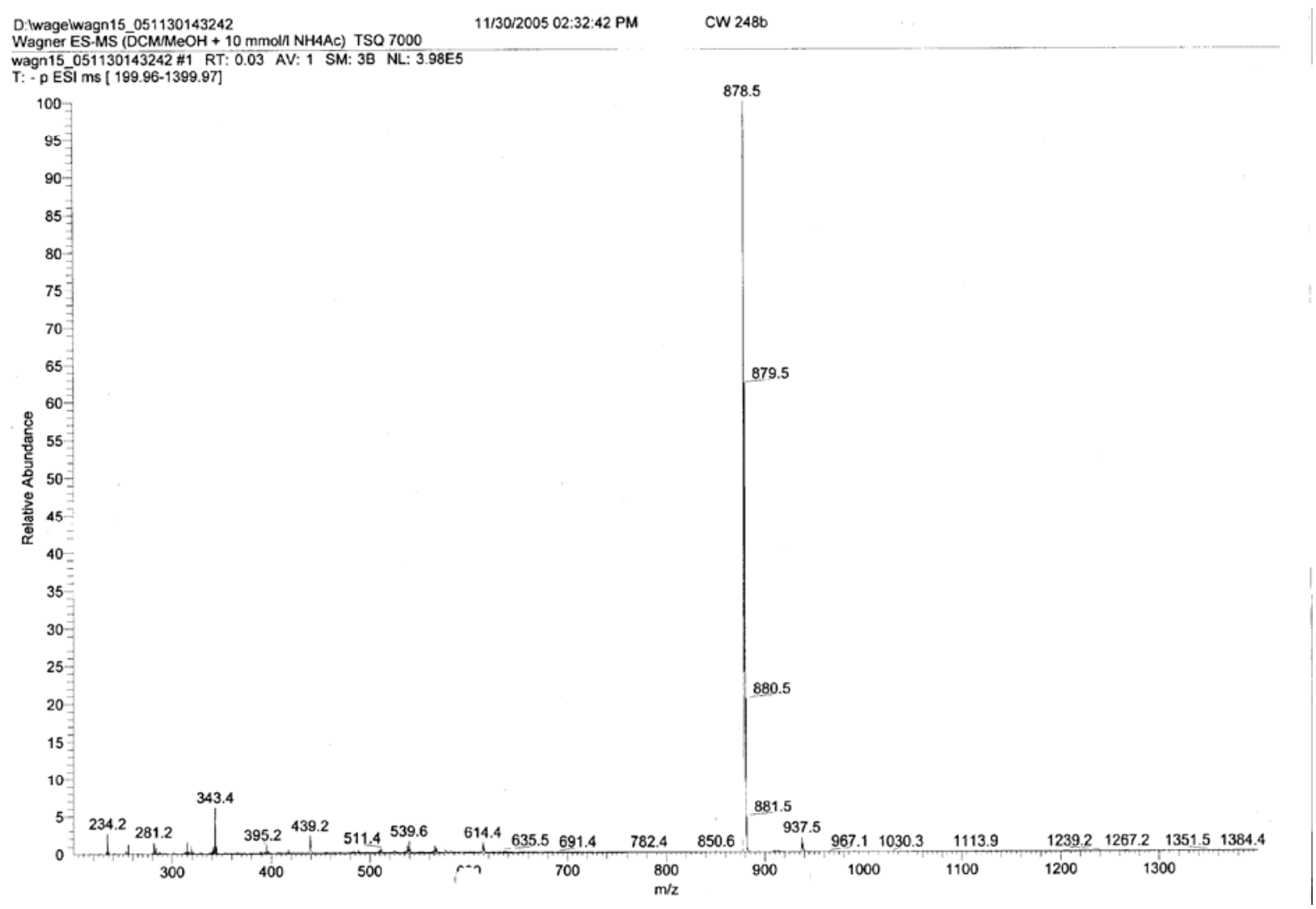

Compound 5

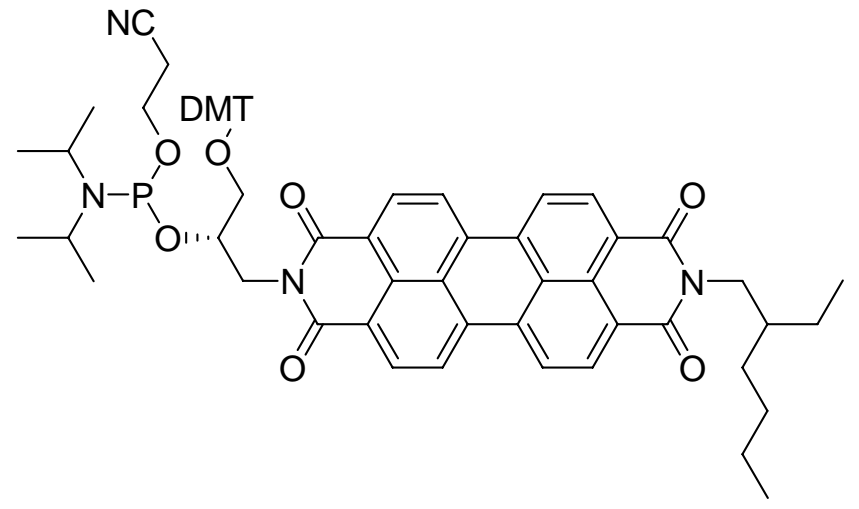

5 
31P NMR

Wagner $\mathrm{Cl}, \mathrm{CW} 273$ in $\mathrm{CD} 2 \mathrm{C} 12$
rau_P31CPD_64 CD2C12 $\{\mathrm{C}: \backslash \mathrm{Bruker} \backslash \mathrm{Xw}$ in-nmr $\}$ Ak_wagenknecht 30

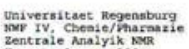
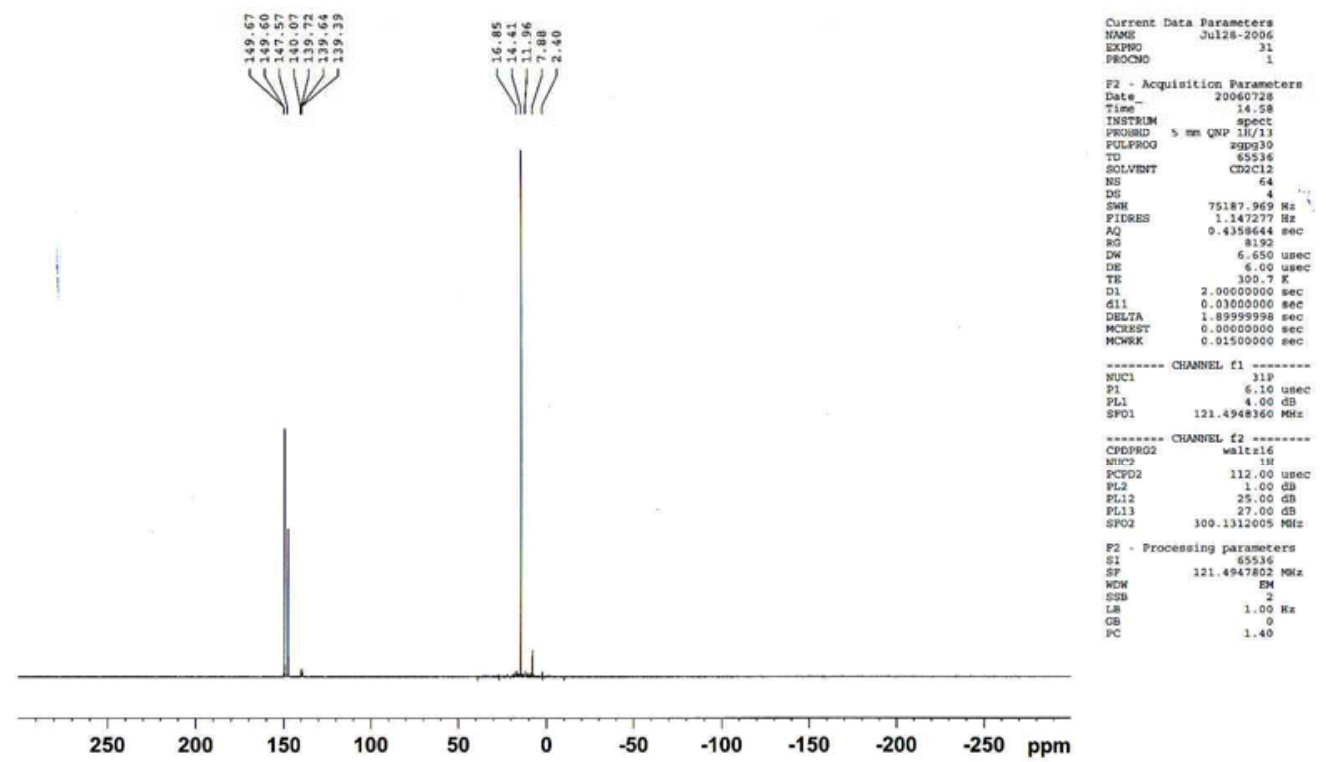

\section{ESI MS}

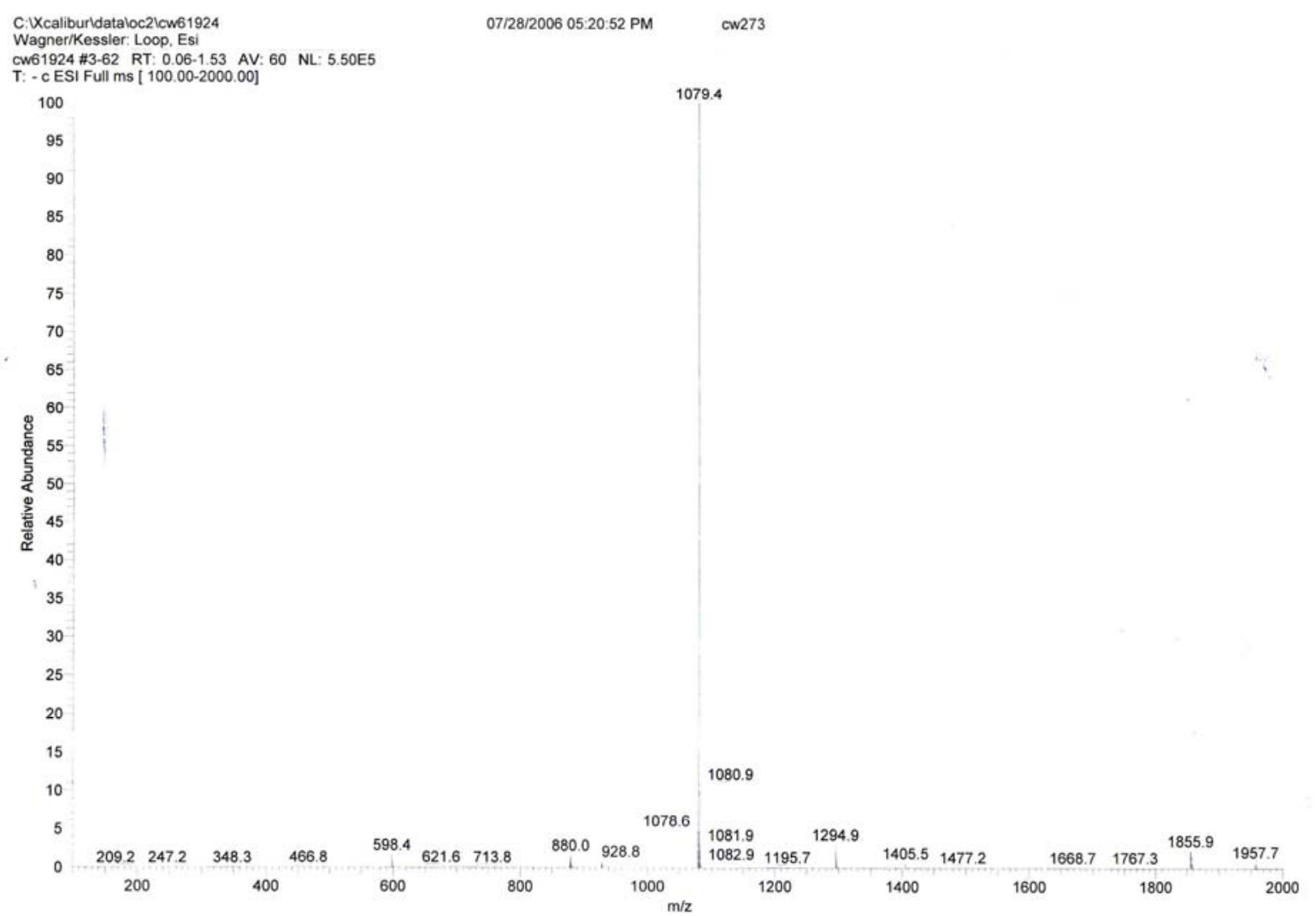


Compound DNA1

3' $C-G-T-A-C-G-T-G-C-A-G-T-A-A-A-A-P e 5^{\prime}$

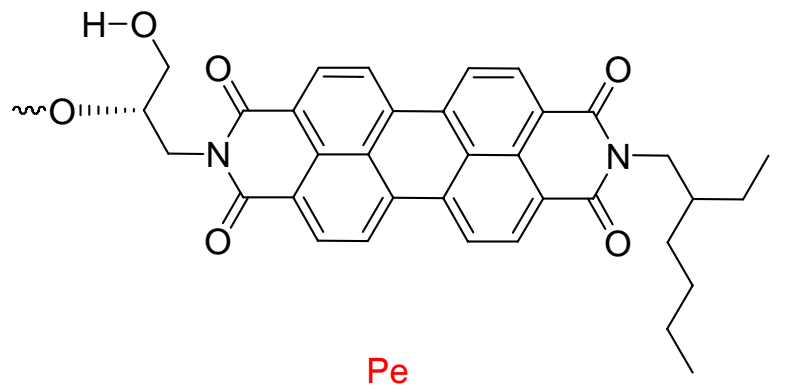

HPLC
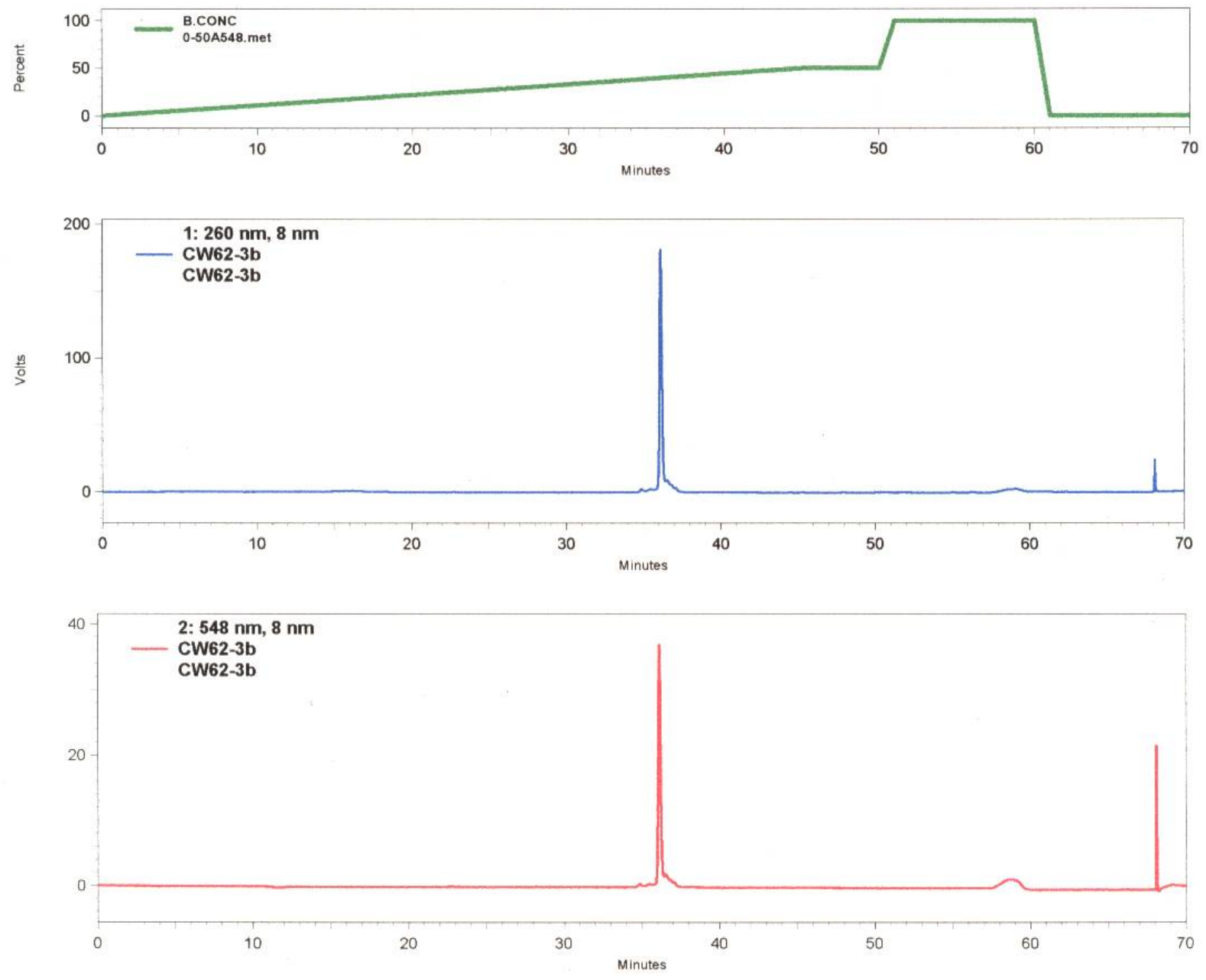
ESI-MS:

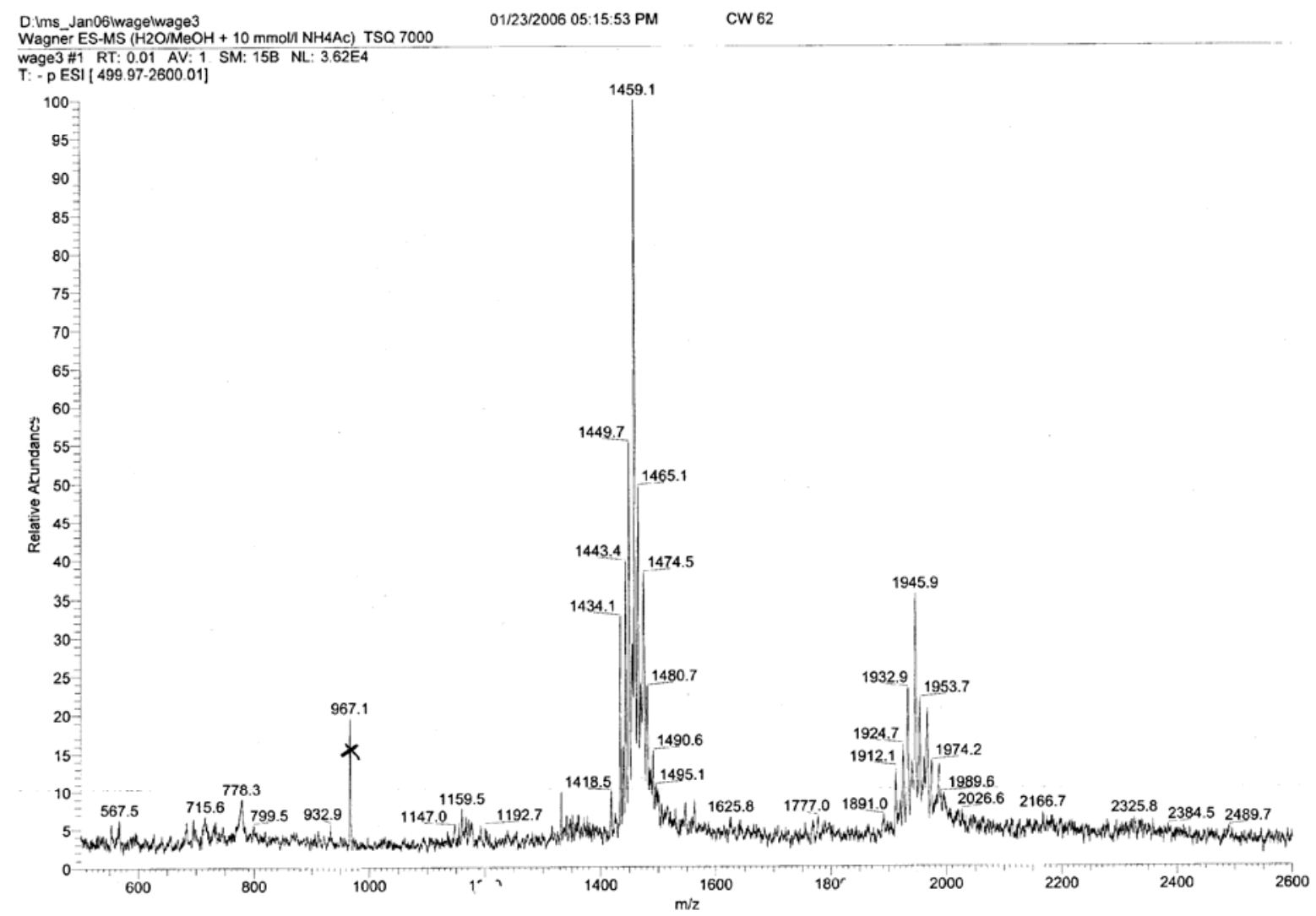

\section{Compound DNA2}

$3^{\prime}$ G-C-A-G-T-A-A-A-A-Pe C-G-T-A-C-G-T 5'

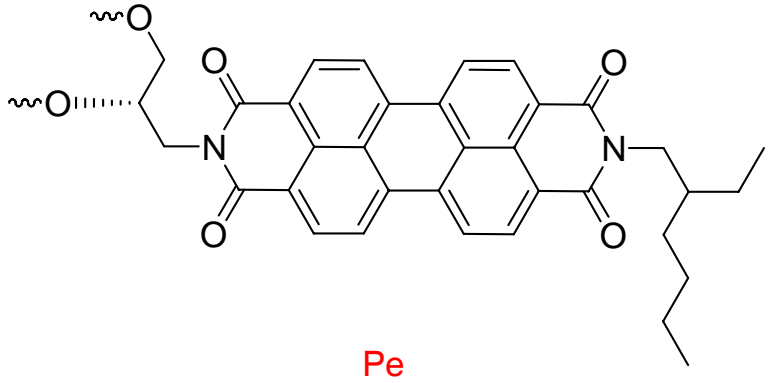



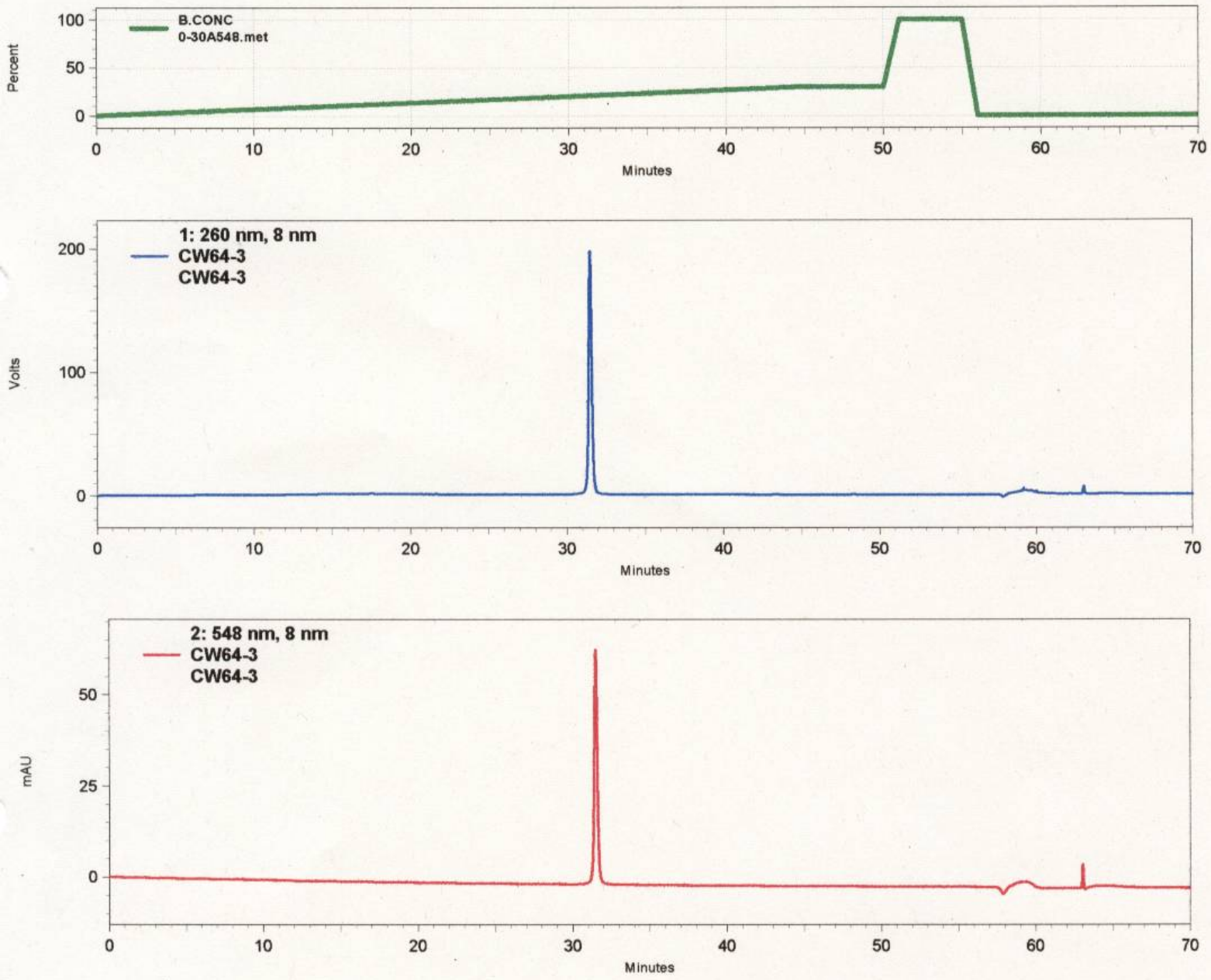


\section{ESI-MS}

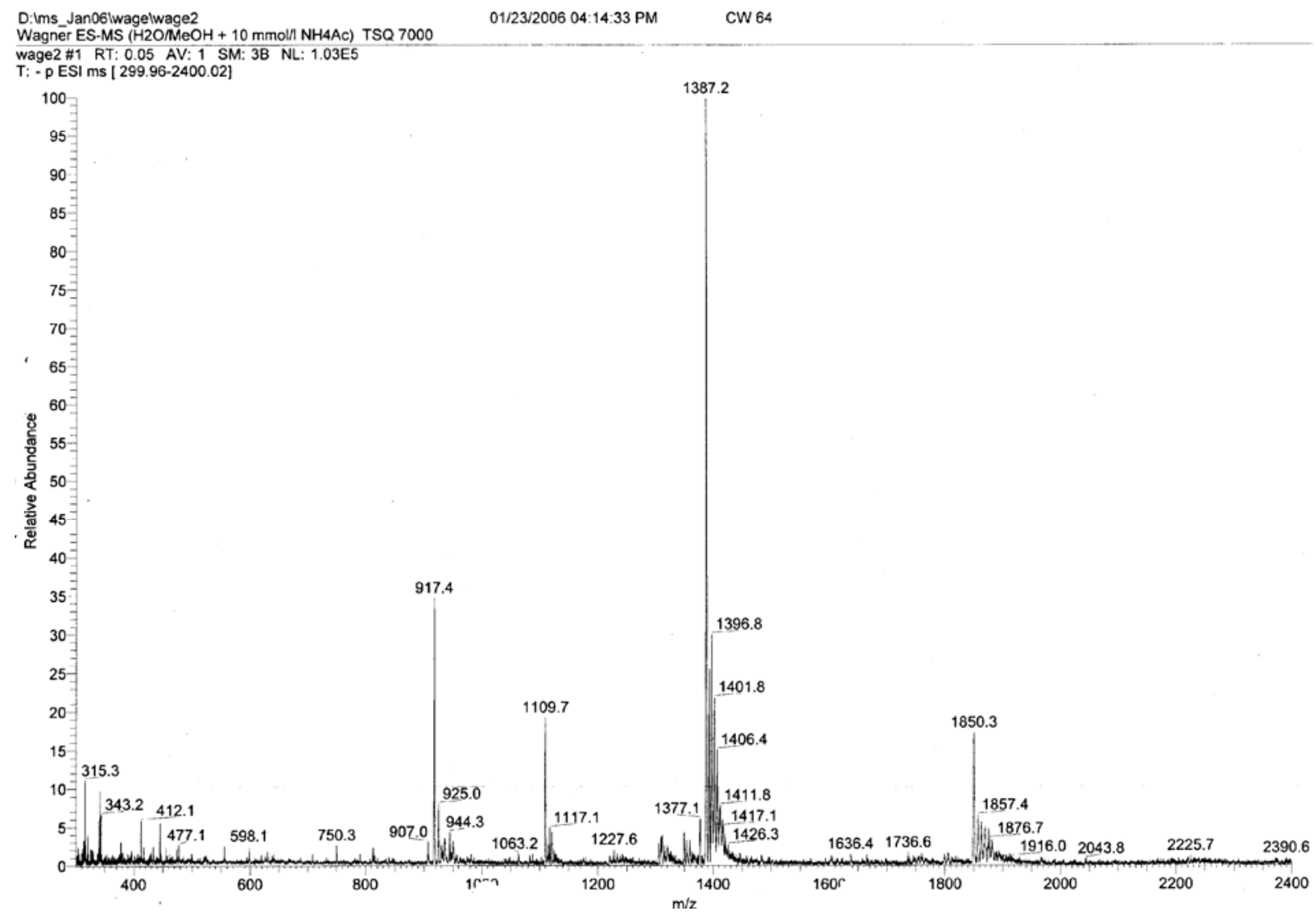

